NBER WORKING PAPER SERIES

\title{
THE IMPACT OF TECHNOLOGICAL CHANGE ON OLDER WORKERS: EVIDENCE FROM DATA ON COMPUTER USE
}

\author{
Leora Friedberg \\ Working Paper 8297 \\ http://www.nber.org/papers/w8297 \\ NATIONAL BUREAU OF ECONOMIC RESEARCH \\ 1050 Massachusetts Avenue \\ Cambridge, MA 02138 \\ May 2001
}

I would like to thank David Autor, Julian Betts, João Miguel Ejarque, Larry Katz, Jim Poterba, Valerie Ramey, and seminar participants at several universities for very useful comments; Johannes Moenius and Andrew Caffrey for excellent research assistance; and the National Institute on Aging and the National Bureau of Economic Research Fellowship in Aging and Health Economics for financial support. Data and programs are available from the author. The views expressed herein are those of the author and not necessarily those of the National Bureau of Economic Research.

(C) 2001 by Leora Friedberg. All rights reserved. Short sections of text, not to exceed two paragraphs, may be quoted without explicit permission provided that full credit, including $($ notice, is given to the source. 
The Impact of Technological Change on Older Workers:

Evidence from Data on Computer Use

Leora Friedberg

NBER Working Paper No. 8297

May 2001

JEL No. J24, J26, O33

\begin{abstract}
New technologies like computers alter skill requirements. This paper explores two related effects of computers on older workers, who use computers less. The evolution of computer use in the Current Population Survey suggests that impending retirement reduces the incentive of older workers to acquire new skills. The Health and Retirement Study shows, further, that computer users retire later than nonusers. This may arise because computer users choose to retire later and also because workers planning later retirement choose to acquire computer skills. Instrumental variables estimates suggest that computer use directly lowers the probability of retirement.
\end{abstract}

\author{
Leora Friedberg \\ Department of Economics \\ University of Virginia \\ 114 Rouss Hall \\ P.O. Box 400182 \\ Charlottesville, VA 22904-4182 \\ and NBER \\ lfriedberg@virginia.edu
}


The proportion of workers using a computer jumped from $24 \%$ in 1984 to $51 \%$ in 1997. Many people have the impression that older workers find it difficult to learn new technologies like computers. In $199740 \%$ of workers aged 60-64 used a computer, $21 \%$ below the average. Nevertheless, in this paper I argue that age alone does not explain why older workers use computers less. Impending retirement, which reduces the time horizon to recoup an investment in new skills, appears to play a major role. Computer users have, in turn, been retiring later than non-users - perhaps because workers with computer skills choose to delay retirement and perhaps because workers planning later retirement choose to acquire computer skills. I use an instrumental variables approach to sort out the impact of computer skills on retirement.

The underlying premise is that new technologies like computers alter jobs and skill requirements in jobs. Case-study evidence supports this view, which is distinct from the unresolved question of the skill-bias of new technologies. If new technologies change skill requirements, older workers will be affected differently than prime-age workers because their skills are of an older vintage. Older workers will also respond differently because impending retirement reduces their time horizon as they consider whether to upgrade their skills. It will be important to understand these effects as the baby boom cohort nears retirement, while technologies continue to change rapidly.

Technological change is difficult to study, however, because it is difficult to observe. Earlier research on older workers used aggregated industry measures of technological change. I use repeated cross-sections from the Current Population Survey that show how computers have spread through the economy. I analyze the evolution of computer use by cohorts in order to understand why older workers use computers less. I 
then use longitudinal data from the new Health and Retirement Study in order to relate computer use to subsequent retirement decisions. Previous studies have emphasized the need to control for other attributes of computer users in order to identify the impact of computers. The HRS allows detailed controls for many attributes of jobs and workers when analyzing the link between computer use and retirement.

\section{BACKGROUND}

I begin this section by describing how technological change can affect workers of different ages. Next, I discuss research on the impact of computerization on jobs and skill requirements, and lastly I describe the computer use data which I will use.

\section{A. Changes in technology and skill requirements}

If new technologies alter jobs and skill requirements in jobs, then older workers will be affected differently than prime-age workers for several reasons. First, older workers have less education on average, so their jobs will more likely be replaced by new technologies. ${ }^{1}$ Second, if skills of older workers are of an older vintage, they are more likely to be made obsolete. Third, workers of all ages decide whether to invest in new skills required to work with new technologies, but older workers have less time to recoup the investment as they approach retirement. For these reasons, the earnings and employment of older workers may be harmed by new technologies. That may, in turn, lead some older workers who lack new skills to retire sooner than they planned.

This view is distinct from the unresolved question of whether new technologies are skill-biased - complementing skilled labor and human capital while substituting unskilled labor. A shift towards skill-biased technological change is a leading explanation for the 
rising dispersion of earnings and employment in the U.S. ${ }^{2}$ If new technologies are complementary with skills or education, it will sharpen the impact on older workers.

A few researchers have studied the impact of technological change on older workers. Juhn (1992) concluded that the rising dispersion of earnings contributed to earlier retirement of low-education workers, relative to high-education workers, since the early 1970s. However, the interaction of age and education is complex; Katz and Murphy (1992) found that relative earnings of older low-education workers declined less than prime-age low-education workers, while earnings of older high-education workers rose less. The asymmetry by education implies an interaction of skill requirements with age or skill vintage. Bartel and Sicherman (1993) focused directly on the impact of technology shocks on older workers. Using industry-level data on productivity growth and training requirements in the 1960s and 1970s, they concluded that training costs associated with unanticipated technological change led workers to retire early.

\section{B. The impact of computerization}

Many studies, including those just mentioned, used indirect measures of technological change. Information on computer usage has become available more recently and offers new insight. Computers have transformed virtually all areas of production, as McConnell (1996) noted. While computers have grown easier to use over time, both employers and individuals continue to devote substantial resources to computer training. For example, the University of Virginia has provided computer training to two to three

\footnotetext{
1 Goldin and Margo (1992) documented the steep rise in educational attainment during the $20^{\text {th }}$ century. 2 Katz and Murphy (1992), Murphy and Welch (1992), Gottschalk (1997), and many others documented increases in inequality since the 1970s. Johnson (1997) and Topel (1997) reviewed the evidence suggesting that the demand for skill rose disproportionately. Goldin and Katz (1998) found evidence of technologyand capital-skill complementarity going back to the early 1900s.
} 
thousand staff per year in over two thousand total workshops during the last four years. The University now furnishes 3.86 training hours per employee per year, up from 0.73 in $1994 .^{3}$

Case studies make it clear that computerization often alters the entire bundle of skills and tasks in jobs. Levy and Murnane (1996) found that computers had been used to automate simple tasks in a financial services firm, but remaining tasks grew more complicated. Bresnahan, Brynjolffson, and Hitt (2001) showed that firms that computerized often incurred substantial training, re-organization, and other adjustment costs.

Some researchers have concluded, further, that computer use and associated job changes generally require more able workers and thus are skill-biased. Brynjolffson and Hitt (1997) and Lehr and Lichtenberg $(1998,1999)$ found that firms purchasing a higher number of computers exhibited greater complementarity with skilled labor. Krueger (1993) estimated that the earnings premium for computer use in the CPS accounts for $1 / 3$ to $1 / 2$ of the rising education premium in the 1980s. Autor, Katz, and Krueger (1998) matched industry data on computer use, investment, and employment of educated workers and concluded that the spread of computers explains $30-50 \%$ of the higher growth in relative demand for skilled workers since 1970.

Research by DiNardo and Pischke (1997), however, casts doubt on the interpretation of computer use data in studies like Krueger's. In German data similar to the CPS, many implements used by white collar workers - computers, pencils, telephones, chairs - are associated with higher earnings. Since using a pencil probably does not raise earnings,

\footnotetext{
${ }^{3}$ I am grateful to Antonio Rice and Roxana Colvin for data from the University's office of Information Technology and Communication. Additional statistics appear in the ITC Progress Report 1999-2000.
} 
DiNardo and Pischke suggested that computer use appears to raise earnings because it is correlated with unobserved attributes of jobs and workers that are increasingly rewarded.

As I show later, computer use rates differ by age in a distinct way that would not be expected if computers simply proxy for pencil use or for many other unobserved job attributes. Thus, I interpret computer use and associated changes in job skills as productive, after controlling for other attributes of computer users and their jobs. The HRS helps in this regard, because it reports unprecedented detail about potential correlates of computer use and retirement - including other required job skills, employment history, and non-wage compensation like pension and health benefits.

\section{Data on computer use}

I use two data sets in this study. The Current Population Survey collects monthly employment data from over 150,000 people, yielding a sample of about 60,000 workers aged 18-64. The October surveys of 1984, 1989, 1993, and 1997 asked workers "Do you directly use a computer at work?" and, if so, for what purposes. ${ }^{4}$ The January 1991 survey asked about job training, including about training in computer skills.

The longitudinal Health and Retirement Study began in 1992, following over 7,600 households with someone born between 1931 and 1941. Every two years the HRS collects detailed data on employment, income, health, etc. The first wave asked workers how often they are required to work with computers. This information has not been closely studied but

\footnotetext{
${ }^{4}$ The 1993 supplement began, "The next set of questions has to do with direct or hands on use of computers.... These questions do not refer to hand-held calculators or games, electronic video games, or systems which do not use a typewriter-like keyboard." As Krueger (1993) pointed out, this targets users of computers with keyboards and monitors, but not many other devices with embedded microprocessors.
} 
is well-suited for analyzing the interaction of computer use and subsequent retirement. ${ }^{5}$ The detailed data on individual and job characteristics are crucial in controlling for other factors that may be correlated with computer use.

\section{PATTERNS OF COMPUTER USE}

This section uses CPS data on computer use by age, over time, and across occupations to infer how computerization affects older workers. Distinct trends in the evolution of computer use suggest that impending retirement plays a key role.

\section{A. Trends in computer use}

Table 1 reports computer use of workers aged 18-64 in the CPS. In $198424.4 \%$ of workers used a computer. Computer use rose 12.9 percentage points by 1989 and 9.3 points by 1993 , but only 4.0 points by 1997 , to $50.6 \%$. While the small increase since 1993 suggests that computerization has reached a plateau, computer purchases remain strong, and I show later that the intensity of computer use continues to deepen.

Table 1 also shows how computer use varies across different types of workers. ${ }^{6}$ $75.9 \%$ of workers with a college education in 1997 used a computer, compared to $36.4 \%$ with only a high school degree. This gulf in computer use by education widened over the period. Women use computers more than men, but controlling for occupation explains virtually all the differential.

\footnotetext{
${ }^{5}$ Hurd and McGarry (1993) analyzed the effect of computer use and other job characteristics on retirement plans, but not on actual retirement. Later HRS waves did not ask about computer use.

6 The same tabulations appear in Krueger (1993) and Autor, Katz, and Krueger (1998). The 1984 and 1989 statistic shown here are very similar but do not exactly replicate those in Krueger's Table 1.
} 


\section{B. Computer use and age}

The "age profile" of computer use in 1997 appears in Figure 1. It is striking to observe that computer use is essentially flat over most ages. The rate of computer use hovers around 54\%, not deviating by more than 3 percentage points at any age from 25 to 53. Figure 2 shows the evolution of the age profiles over time. The dominant trend is a steady upward shift in computer use at all ages. The age profiles were slightly more peaked early on and have spread out as early users aged.

The long flat range of computer use in the age profiles suggests that being old or many years out of school does not by itself keep people from using computers. Workers in their fifties in 1997 were very unlikely to have used a computer in college, for example. People apparently acquire computer skills as needed for their jobs, largely independent of age - except for the oldest workers, who use computers significantly less.

This is also evident in the evolution of computer use within each cohort. Figure 3 shows observations for the same cohort in different years, rather than for the same age in different years as in Figure 2. For example, it shows the evolution of computer use for the cohort aged 40 in 1997, 36 in 1993, 32 in 1989, and 27 in 1984. This makes it clear that today's oldest workers have only recently fallen behind. People now in their fifties and sixties used computers at a substantially lower rate in 1997, but at only a slightly lower rate in 1984 and 1989.

The gains in computer use among successive cohorts appear in Table 2. The influence of approaching retirement is most apparent for older cohorts in 1993, shown in the middle rows. People aged 60-64 in 1993 kept close to younger workers earlier, from 1984 to 1989 ; their computer use rose 8.9 percentage points, compared to 12.9 for people aged 
45-49 in 1993. From 1989 to 1993 , however, their gain was 4.1 points, compared to 11.4 for the younger group. Thus, they failed to keep up with younger workers as they neared retirement, though they had previously. ${ }^{7}$

These cohort trends suggest an alternative explanation for the low rates of computer use at older ages. Age by itself does not explain it - nor do years since schooling, nor the obsolescence of skills. Those backward-looking factors should generate a sloping, not flat, age profile. The age profiles suggest the importance of a forward-looking factor like impending retirement. The decision at any age to use a computer requires an investment in new skills that pays off over time. Therefore, a worker's time horizon affects whether they end up using a computer.

\section{Computer use in the HRS}

The Health and Retirement Study asked workers in 1992 how frequently they use a computer on the job. Table 3 shows that $48.9 \%$ of workers aged $50-59$ and $41.9 \%$ aged 60 62 used a computer at least some of the time. Over half of users report using the computer most or all of the time, with identical intensity of use by age. Age, education, and occupational differences in computer use resemble those in the CPS. The overall rates of use are higher, perhaps because the HRS focuses on frequency of use and also lacks the careful lead-in defining computer use. I will return to the HRS data later to analyze retirement decisions of computer users and non-users.

\section{Computer use across occupations}

\footnotetext{
${ }^{7}$ Computer use grew much less since 1993, so the aging of existing users is the dominant effect between 1993 and 1997.
} 
Computer use varies enormously by occupation. Table 1 shows that the computer use rate in 1997 was $70-80 \%$ among professionals, managers, and clerical workers, but $25 \%$ or less among skilled and unskilled blue-collar workers. ${ }^{8}$ Computers spread at different rates as well. In this subsection I show, first, that age differences in occupation and education do not explain age differences in computer use. Second, I show that computer use of older cohorts fell behind in occupations with recent jumps in computer use, compared to those with high use early on.

Table 4 reports regressions of 1993 computer use that include controls for age, occupation, and education. Adding 45 occupation and 4 education dummies in column (4) shrinks coefficients on age dummies by $1 / 4$ to $1 / 3$. For example, the computer use rate at age 23-39 is 16.5 percentage points higher than at age $60-64$, and it remains 12.8 points higher after adding education and occupation controls. Thus, within-occupation and education differences explain most of the age differences in computer use.

The pace of computerization also varied across occupations. Some jobs had high rates of computer use early on, while others had jumped recently. ${ }^{9}$ These differences in timing influence computer use by aging cohorts. Table 5 reports regressions, for different cohorts, of individual computer use on both levels and changes in average use in the person's occupation and industry. The point is to show how the pace of computerization affected computer use as particular cohorts aged. Not surprisingly, the estimates show that average computer use in an occupation, and its interaction with the industry average, is a key determinant of whether someone uses a computer.

\footnotetext{
${ }^{8}$ Computer use in 45 two-digit occupations ranged from $4 \%$ to $97 \%$. The coefficient of variation across occupations is almost identical at the one and two-digit levels.

${ }^{9}$ High computer-use occupations throughout include engineering and some managerial and clerical jobs. Among others, teachers, public administrators, and health workers had major gains since 1984.
} 
The estimates also show that the recent change in computer use has a negative effect for older workers only. Thus, recent increases in computer use have a large negative statistically significant coefficient for older cohorts, but this does not occur for earlier changes or for younger cohorts. Suppose someone aged 60-64 in 1993 works in an occupation and industry where $50 \%$ of prime-age workers have used a computer since 1984 ; the coefficients imply that the worker has a $54 \%$ chance - about the same - of using a computer. In contrast, if computer use in the job jumped from $10 \%$ to $30 \%$ to $50 \%$ between 1984,1989 , and 1993 , the worker has only a $14 \%$ chance of using a computer. A worker aged 50-59 has a 59\% chance of using a computer in the first case, but only a $26 \%$ chance in the second.

These results highlight the interaction between technological change and impending retirement. The evolution of the age profiles showed that the oldest workers fall behind only as they approach retirement age. Here, the evidence shows that the oldest workers fall behind only if computers use jumps in their jobs.

\section{E. How workers use computers}

The CPS asked workers what they use computers for, and I grouped about twenty possible answers into broad tasks. For example, word processing, databases, and spreadsheets are classified as common applications. Table 6 shows that common applications remain the most popular task, reported by $71 \%$ of computers users in 1997.

The table also shows that the intensity of computer use has risen - the number of specific uses reported by each computer user rose from an average of 4.0 in 1993 to 4.6 in 1997, even though the number of usage categories reported in the CPS actually fell from 22 to 16 over the same period. The oldest and youngest workers use their computers less 
intensively, however. Computer users aged 60-64 reported an average of 4.0 specific uses, $14 \%$ less than the 4.7 reported at ages $23-49$. The differential intensity of use actually rises slightly if one controls for education and occupation. These patterns suggest that the oldest and youngest workers who use a computer have acquired fewer computer-related skills than prime-age workers.

Additional data on computer use and training from the January 1991 CPS appear in Table 7. We see the same age profile of computer use. ${ }^{10}$ Rates of job training differ by age as well. $48.8 \%$ of workers aged $40-49$ received some training in their current job, compared to $42.8 \%$ at ages $50-59$ and $34.7 \%$ at ages $60-64 .^{11}$ Older workers also received less training in computer skills. $35.4 \%$ of workers aged $40-59$ who received training were trained in computers, versus $29.4 \%$ at ages $60-64$. These patterns support the key hypothesis in this paper - workers tend to get less training in new skills as they near retirement.

\section{COMPUTER USE AND RETIREMENT}

The age profiles of computer use suggest that retirement reduces the value of acquiring computer or other productive skills. It follows that a change in technology which requires new skills may lead some workers lacking those skills to retire early. Others who acquire the new skills may choose to delay retirement. The rest of this paper analyzes the interaction of computer use and retirement using longitudinal data from the HRS.

\footnotetext{
10 The age differentials are almost identical to the October 1989 and 1993 data, though the rates of computer use are higher, as in the HRS. $72.7 \%$ of users aged 60-64 reporting everyday use, versus $77.5 \%$ at ages 23-39

11 The age differences in job training rates persist with controls for occupation and occupational and employer tenure.
} 
Table 8 shows retirement data from the first three waves of the HRS. Among workers aged 50-62 in wave 1, 75.6\% were still working four years later in $1996 .^{12}$ Computer users were significantly less likely to retire. $78.4 \%$ were working four years later, compared to $73.0 \%$ of non-computer users - so non-users were $25 \%$ more likely to leave work.

A stylized model can explain this relationship. Consider a worker who lacks a productive new skill (like computer use) that could be acquired with training. The employee will get trained in the new skill, $S=1$, if the expected benefit $B(S)$ exceeds the cost $\mathrm{C}(\mathrm{S})$ incurred today:

$$
S=1 \text { if } B(S)=\sum_{t=n+1}^{R} \frac{E\left[b_{t}(S)\right]}{(1+r)^{t-n}}>C(S)
$$

Future per-period benefits of training $b_{t}(S)$ are discounted and may be uncertain; a new technology could make current skills obsolete, for example. Benefits stop accruing at the retirement date $R$, also a choice variable. Therefore $S=S(R)$, and for a given $R, \partial S(R) / \partial R \geq$ $0^{13}$

The training decision ultimately depends on various factors,

$$
\mathrm{S}=\mathrm{S}\left(\mathrm{P}^{\mathrm{S}}, \mathrm{F}^{\mathrm{S}}, \mathrm{R}\right)
$$

which influence the costs and benefits of training, including both personal characteristics $\mathrm{P}^{\mathrm{S}}$ (other skills, overall ability) and firm characteristics $\mathrm{F}^{\mathrm{S}}$ (productivity of the new skill). The intended retirement date depends on related variables,

$$
\mathrm{R}=\mathrm{R}\left(\mathrm{P}^{\mathrm{R}}, \mathrm{F}^{\mathrm{R}}, \mathrm{S}\right)
$$

\footnotetext{
${ }^{12}$ Following much of the retirement literature, I use the objective measure of exit from employment, rather than self-reported retirement.

13 The training decision may be made by the employee or employer, depending on who pays the costs and gets the benefits. The firm must infer $\mathrm{R}$ if it decides about training, so it may under-train if older workers
} 
again including personal characteristics $\mathrm{P}^{\mathrm{R}}$ (health, assets) and firm characteristics $\mathrm{F}^{\mathrm{R}}$ (earnings, retirement benefits). If $\mathrm{S}=0$ and $\mathrm{R}=\mathrm{t}$, the worker does not get trained and retires immediately. Moreover, a sudden shift in skill requirements that reduces expected earnings could cause immediate retirement. In general, the training decision and future retirement plans are decided simultaneously. A worker who was planning to retire soon may delay, while a worker who was planning to retire later may retire sooner (though not immediately) through a wealth effect resulting from training.

This discussion shows two reasons why someone who acquires new skills may retire later than someone who does not. First, a decision to get training reflects a pre-existing intention to continue working; and second, training improves work opportunities and may cause a delay in retirement. Thus, we may observe non-computer users retiring early because they intended to retire early and did not get computer skills and because computerization reduces the value of their skills.

For the purpose of understanding future retirement patterns, the key hypothesis is that acquiring new skills induces a worker to delay retirement. This hypothesis can be tested in two distinct ways. One approach is to model and estimate (2) and (3), but many important variables are not observed. ${ }^{14}$ The other approach is to instrument for S, whether a person was trained or uses a computer. A valid instrument is correlated with computer use but otherwise uncorrelated with intended and actual retirement. The instrumental variables approach amounts to asking whether exogenous computer training - giving someone productive computer skills and a computer - will lead to later retirement on average.

cannot credibly convey private information about retirement plans. This consideration is omitted here, but it does not change the basic conclusions.

${ }^{14}$ Most importantly, we observe neither when a worker got trained, nor retirement plans. 
The instrument I use here is average computer use by prime-age workers in the same occupation and industry. High computer use signals that computers are productive relative to training costs, so even older workers near retirement are more likely to use them. The underlying assumption is that average use for prime-age workers who are far from retirement should not be otherwise correlated with older workers' retirement plans, after controlling for other characteristics. I use the detailed HRS data to control for many attributes of workers and jobs that may be correlated with computer skills and retirement. After presenting the results, I explore sensitivity to this identifying assumption.

\section{ESTIMATING THE IMPACT OF COMPUTER USE}

Non-computer users in the HRS retire sooner, possibly for two reasons: lack of computer skills makes work less attractive, and the intention to retire soon diminishes the value of acquiring computer skills. This section instruments for computer use in order to estimate its direct impact on retirement.

\section{A. First stage estimates of computer use}

Table 9 reveals a strong effect of average computer use by prime-age workers on computer use by older workers in the same occupation and industry. ${ }^{15}$ In specification (1) without covariates, occupational computer use has a major impact, particularly in high-use industries. This mirrors results from the CPS in Table 3. Specification (2) reports the firststage regression, which includes additional worker and job covariates. The occupation and industry effects diminish a little but still account for most of the explained variation. The

\footnotetext{
15 These and the rest of the estimates in this paper are reported from a linear probability model; probits yield very similar results. Average computer use is computed in the 1993 CPS for 17 occupation and 13 industry codes that match those in the HRS public release.
} 
estimates imply that if average computer use is $50 \%$, instead of $40 \%$, an older worker is 8.8 percentage points more likely to use a computer.

Specification (3) adds more potential instruments - changes in average rates of computer use - to control for the pace of computerization. As in the CPS, older workers are less likely to use computers in jobs that recently computerized. The magnitudes differ at least in part because the HRS aggregates occupation and industry codes.

\section{B. OLS estimates of retirement}

The main results in Table 10 focus on whether someone who works in 1992 is still working four years later. A series of covariates are added in sequence. Specification OLS-1 shows that the positive effect of computer use on work persists when controlling for age. ${ }^{16}$ OLS-2 includes standard demographic controls and omits computer use. Educated workers are much more likely to continue working, a typical finding. Computer use, added in OLS3, now has a smaller effect, since educated workers are much more likely to use a computer. ${ }^{17}$

OLS-4 adds numerous individual and job characteristics only available in the HRS.

For example, I include controls for the usual retirement age in the worker's job; pension and health benefits available after retirement; and recent hospitalization. ${ }^{18}$ Adding these variables in OLS-4 raises the computer use coefficient. It is significant with $90 \%$ confidence and implies that computer users are 2.2 percentage points, or $12.3 \%$, less likely to have stopped working four years later. This accounts for about half of the raw difference

\footnotetext{
${ }^{16}$ Age dummies control for possible spurious correlation as computer use drops while retirement rises. In fact, age has little effect when the full set of covariates are included in OLS-4.

${ }^{17}$ The sample in the preliminary specifications, OLS-1 through 3, is restricted to be the same as in OLS-4, when numerous covariates are added. Similar estimates are obtained from the entire HRS sample.
} 
in retirement between computer users and non-users. The estimates are similar in both two year intervals.

Most of the HRS variables have the expected signs, and many are significant. For example, someone who has a defined benefit pension and is older than the benefit eligibility age is 12.1 percentage points less likely to continue working. Someone with health insurance from an employer is 6.0 points more likely to continue working, but someone with retiree health insurance is 7.6 points less likely. Log hourly earnings do not significantly affect retirement and do not change the estimated computer use effect. This is important to note because Krueger (1993) showed that computer users have higher earnings; if other skill-related characteristics correlated with computer use also affect retirement, including earnings would reduce the estimated computer use effect.

Since the instruments vary only by occupation and industry, it is crucial to know how occupation and industry characteristics directly affect retirement. Added to the parsimonious specification in OLS-3, occupation dummies are jointly significant at $92 \%$ confidence and industry dummies at $82 \%$. Added along with the detailed HRS controls in OLS-4, confidence levels drop to $84 \%$ and $70 \%$ respectively, below conventional levels of significance. Therefore, the HRS variables - and the usual retirement age and pension plan variables in particular - capture key job attributes correlated with retirement. The remaining influence of occupation and industry, while not negligible, is no longer statistically significant.

${ }^{18}$ The full set of coefficient estimates for OLS-4 and IV-4a are reported in the appendix. Other results are available from the author. 


\section{Instrumental variables estimates of retirement}

Table 11 reports instrumental variables estimates. As before, IV-3 includes basic demographic controls as in OLS-3, while IV-4a and IV-4b add the rich set of controls from the HRS as in OLS-4. IV-4a instruments with average computer use in the same occupation and industry, and IV- $4 \mathrm{~b}$ adds the changes in computer use.

The estimated computer use effect remains large in each specification and suggests that computer use directly induces delays in retirement. The point estimate in IV-4a implies that using a computer makes someone 7.1 percentage points more likely to continue working, a strong effect. With the relatively large standard errors, we cannot reject that the IV estimates are different from OLS. Adding the additional instruments for ongoing changes in computer use incorporates more information about the pace of computerization. The estimate in IV-4b falls by a little less than $10 \%$ and remains statistically significant. The estimate implies that using a computer makes someone 6.6 percentage points less likely to stop working, or $27.5 \%$; holding everything else constant, the median retirement age if everyone used a computer would occur 12 months later. ${ }^{19}$

Instrumenting has little effect on the rest of the coefficients; this implies that other occupation and industry characteristics correlated with computer use are not being picked up in the IV results. The computer effect is stronger later on, from 1994 to 1996, perhaps because computer use grew more important over this period.

When estimated separately, the computer use effect grows with age. The coefficients are $0.013(0.045)$ for ages 50-54, $0.086(0.056)$ for 55-59, and $0.218(0.135)$ for

\footnotetext{
${ }^{19}$ Ultimately, the estimates could be evaluated in terms of the implied retirement response to higher earnings. However, structural retirement models like the one in Rust and Phelan (1997) do not offer a strong basis for comparison because they used data from the 1970s and lacked information on important
} 
60-62, though they are not statistically different. In contrast, the OLS estimates are quite similar across ages. These differences suggest a shift - retirement plans influence computer use of the sample's younger workers so the IV estimate is small, while computer use influences retirement of older workers. In OLS estimates, occupation and industry effects are highly insignificant for younger ages but matter somewhat for ages $60-62 .^{20}$ Thus, the strongest result is the IV estimate for ages 55-59.

Research on prime-age workers shows that women have more elastic labor supply than men; computer use may therefore have greater influence on women's retirement.

Separating the sample by gender raises the standard errors, but the point estimates indicate a stronger effect of computer use in delaying retirement of women, who have a coefficient of $0.093(0.049)$, compared to men, with a coefficient of $0.064(0.055)$.

The HRS also asks about retirement plans. Workers in this sample plan to retire in 7.7 years on average. Regressing years to retirement on computer use (as in OLS-4) yields a coefficient of $0.372(0.134)$, so computer users plan to work significantly longer.

Instrumenting with average use (as in IV-4a) yields a coefficient of $0.676(0.313)$. Thus, using a computer causes a delay in planned retirement of two-thirds of a year, or $9.0 \%$.

\section{Are the instruments valid?}

The conclusion that computer use makes it attractive to keep working is driven by people in high computer-use jobs, who are much more likely to use computers. The IV estimates are larger, however, not smaller than the OLS estimates - evidently because some

factors such as pension and health insurance coverage. Structural models have not yet been estimated using the HRS, which is still underway.

${ }^{20}$ Earlier, I discussed adding occupation and industry effects in OLS-4 estimates. For ages 50-54 and 5559 , confidence levels for joint significance are under 50\%. They are borderline significant for ages 60-62, and in that case the instruments may reflect other influences on retirement; this is discussed next. 
non-users in high-use jobs retire later than non-users in low-use jobs. This raises concern about omitted variables, other occupation and industry attributes correlated with average computer use and influencing retirement. This section details several strategies to assess the validity of the instruments, in light of these concerns.

- As discussed earlier, unrestricted occupation and industry effects had a statistically insignificant impact when added to the OLS estimates along with the detailed HRS controls.

- While average computer use by occupation plays a key role in the first stage regression, industry use adds little explanatory power. ${ }^{21}$ This suggests the possibility of including unrestricted industry effects in the main regression and instrumenting only with occupational computer use. The resulting computer use estimate rises slightly to 0.077 (0.041). The estimates still rise with age, and, for example, the estimate for ages 55-59 of $0.092(0.062)$ is almost the same.

- Another strategy is to add more variables from the HRS. Several variables detailing other job requirements - physical effort, intense concentration, dealing with people, high stress, etc. - do not significantly affect retirement nor reduce the explanatory power of computer use. The only additional variable that matters is an indicator for responsibility for pay and promotion decisions, asked of non-self-employed workers. Added to OLS-4, pay and promotion responsibility has a similar impact on retirement as computer use. Added to IV4a, it lowers the computer use effect by about $10 \%$, from $0.075(0.039)$ to $0.066(0.040)$, just significant at $90 \% .^{22}$

\footnotetext{
${ }^{21}$ In the first stage, including only the occupational average yields an $\mathrm{R}^{2}$ of 0.273 ; adding the industry average and their interaction raises it to 0.288 .

${ }^{22}$ The estimated effect of the pay/promotion variable is $0.031(0.017)$ in OLS and $0.025(0.018)$ in IV.
} 
- Outside sources may also yield information about occupation and industry characteristics.

To this end, I assembled data on retirement rates from the late 1970s, before the 1981 launch of the personal computer. ${ }^{23}$ Indicators of earlier retirement rates would kill the estimated computer use effect if they capture omitted job characteristics that persist today, especially since industry retirement patterns remain similar. ${ }^{24}$ When measures of earlier occupation and industry retirement rates are added to OLS-4, the coefficient on computer use is almost unchanged. When they are added to IV-4a, the coefficient is $0.057(0.040)$, down from $0.071(0.037)$. So, while part of the variation in average computer use could reflect other influences on retirement, the estimate remains large, though imprecisely measured.

Thus, after introducing several measures of other job attributes, the computer use effects remain close to the original estimates, especially for ages 55-59. Though these estimates are not precise, the results suggest that computer use has an independent effect on retirement, raising the probability of continuing to work by up to $25-30 \%$ over a four year period.

\section{CONCLUSION}

Rates of computer use are remarkably similar for all but the oldest workers, suggesting that most workers acquired computer skills as needed - even when they were long out of school. The oldest cohorts kept pace with the spread of computers at younger ages, and lagged only in jobs that computerized rapidly and recently. These patterns

\footnotetext{
23 I am grateful to Larry Katz for the suggestion of adding earlier retirement rates. These measures are described in the appendix. Adding average training rates from the January 1991 CPS did not affect the estimates.

${ }^{24}$ The correlation coefficient between industry retirement rates in the 1990s and the late 1970s is 0.679 . Occupational retirement rates are not closely related. The results are the same using retirement data from the early 1980s, when occupation codes are much simpler to match to present codes.
} 
indicate that impending retirement, not age alone, influences the responses of older workers to computerization and other technological changes.

In turn, changes in skill requirements may affect retirement plans. Computer users were $25 \%$ more likely to continue working between 1992 and 1996 than non-users. That might occur because computer users have valuable skills which lead them to delay retirement and also because computer users already intend to retire later and thus find it worthwhile to acquire skills. I use an instrumental variables approach to sort out this interaction. I estimate the impact of computer use on retirement by predicting computer use with the average in a worker's occupation and industry, while controlling for many other characteristics of workers and their jobs that are potentially correlated with computer skills and retirement. The results indicate that computer use leads directly to later retirement. The estimates are not very precise, but they imply that computer use raises the likelihood of continuing to work by up to $25-30 \%$. These effects are strongest for workers in their late fifties.

It will be important to learn more about the impact of new technologies on older workers. Policy efforts designed to encourage later retirement might have limited success if older workers face pressure from technological change. On the other hand, any future delays in retirement, perhaps resulting from rising life spans or changes in Social Security and private pensions, may induce older workers to invest in new skills as technologies evolve. 


\section{REFERENCES}

Autor, David, Lawrence Katz, and Alan Krueger. 1998. "Computing Inequality: Have Computers Changed the Labor Market?” The Quarterly Journal of Economics, Vol. 113, No. 4, pp. 1169-214.

Bartel, Ann, and Nachum Sicherman. 1993. "Technological Change and Retirement Decisions of Older Workers." Journal of Labor Economics, Vol. 11, No. 1, part 1, pp. 16283.

Bresnahan, Timothy, Eric Brynjolfsson, and Loren Hitt. 2001. “Information Technology, Workplace Organization and the Demand for Skilled Labor: Firm-Level Evidence." Quarterly Journal of Economics, forthcoming.

Brynjolfsson, Eric, and Loren Hitt. 1997. "Computing Productivity: Are Computers Pulling Their Weight?" Unpublished paper, Sloan School of Management, Massachusetts Institute of Technology.

DiNardo, John, and Jörn-Steffen Pischke. 1997. "The Returns to Computer Use Revisited: Have Pencils Changed the Wage Structure Too?” The Quarterly Journal of Economics, Vol. 112, No. 1, pp. 291-304.

Friedberg, Leora. 1999. "The Impact of Technological Change on Older Workers: Evidence from Data on Computers." UCSD Department of Economics Discussion Paper No. 99-11.

Goldin, Claudia, and Larry Katz. 1998. "The Origins of Technology-Skill Complementarity." The Quarterly Journal of Economics, Vol. 113, No. 3, pp. 693-732.

Goldin, Claudia, and Robert Margo. 1992. "The Great Compression: The Wage Structure in the United States at Mid-Century." The Quarterly Journal of Economics, Vol. 107, No. 1, pp. 1-34.

Gottschalk, Peter. 1997. "Inequality, Income Growth, and Mobility: The Basic Facts." Journal of Economic Perspectives, Vol. 11, No. 2, pp. 21-40.

Hurd, Michael, and Kathleen McGarry. 1993. "The Relationship Between Job Characteristics and Retirement." National Bureau of Economic Research Working Paper No. 4558.

Johnson, George. 1997. "Changes in Earnings Inequality: The Role of Demand Shifts." Journal of Economic Perspectives, Vol. 11, No. 2, pp. 41-54.

Juhn, Chinhui. 1992. "Decline of Male Labor Market Participation: The Role of Declining Market Opportunities.” The Quarterly Journal of Economics, Vol. 107, No. 1, pp. 79-122. 
Katz, Lawrence, and Kevin Murphy. 1992. "Changes in Relative Wages, 1963-1987:

Supply and Demand Factors." The Quarterly Journal of Economics, Vol. 107, No. 1, pp. 134.

Krueger, Alan. 1993. "How Computers Have Changed the Wage Structure: Evidence from Micro Data.” The Quarterly Journal of Economics, Vol. 107, No. 1, pp. 35-78.

Lehr, Bill, and Frank Lichtenberg. 1998. "Computer Use and Productivity Growth in Federal Government Agencies, 1987-92." Journal of Industrial Economics, Vol. 46, No. 2, pp. 257-279.

Lehr, Bill, and Frank Lichtenberg. 1999. "Information Technology and Its Impact on Productivity: Firm-Level Evidence from Government and Private Data Sources, 19771993." Canadian Journal of Economics, Vol. 32, No. 2, pp. 335-62.

Levy, Frank, and Richard Murnane. 1996. "With What Skills are Computers a Complement?" American Economic Association Papers and Proceedings, Vol. 86, No. 2, pp. 258-62.

McConnell, Sheila. 1996. "The Role of Computers in Reshaping the Work Force." Monthly Labor Review, Vol. 119, No. 8, pp. 3-5.

Rust, John, and Christopher Phelan. 1997. "How Social Security and Medicare Affect Retirement Behavior in a World of Incomplete Markets.” Econometrica, Vol. 65, No. 4, pp. 781-832.

Topel, Robert. 1997. "Factor Proportions and Relative Wages: The Supply-Side Determinants of Wage Inequality." Journal of Economic Perspectives, Vol. 11, No. 2, pp. $55-74$. 


\begin{tabular}{|c|c|c|c|c|}
\hline \multicolumn{5}{|c|}{$\begin{array}{l}\text { TABLE } 1 \text { Rates of Computer Use at Work: } \\
\text { The percentage of workers who use a computer }\end{array}$} \\
\hline & 1984 & 1989 & 1993 & 1997 \\
\hline All workers & 24.4 & 37.3 & 46.6 & 50.6 \\
\hline \multicolumn{5}{|l|}{ Age } \\
\hline $18-22$ & 16.9 & 25.7 & 28.9 & 31.8 \\
\hline $23-39$ & 28.5 & 40.9 & 49.2 & 52.6 \\
\hline $40-49$ & 23.6 & 40.3 & 51.3 & 54.9 \\
\hline $50-59$ & 19.7 & 32.0 & 43.9 & 50.7 \\
\hline $60-64$ & 14.4 & 23.3 & 32.7 & 40.0 \\
\hline \multicolumn{5}{|l|}{ Education $^{\mathrm{a}}$} \\
\hline$<$ High school & 4.9 & 7.7 & 9.5 & 11.7 \\
\hline High school & 18.5 & 28.5 & 34.1 & 36.4 \\
\hline Some college & 31.2 & 44.8 & 53.1 & 56.2 \\
\hline College + & 41.2 & 58.6 & 70.2 & 75.9 \\
\hline \multicolumn{5}{|l|}{ Gender } \\
\hline Male & 20.8 & 31.9 & 41.1 & 44.8 \\
\hline Female & 29.3 & 43.6 & 53.2 & 57.3 \\
\hline \multicolumn{5}{|l|}{ Occupation } \\
\hline Professional \& technical & 38.1 & 54.4 & 65.7 & 73.1 \\
\hline Managers \& administrators & 42.5 & 61.8 & 73.7 & 78.7 \\
\hline Sales & 23.9 & 35.5 & 49.8 & 55.8 \\
\hline Clerical & 47.4 & 66.8 & 77.4 & 78.6 \\
\hline Craftsmen & 10.1 & 15.2 & 23.5 & 25.3 \\
\hline Operatives & 5.8 & 9.6 & 15.7 & 18.6 \\
\hline Laborers & 3.2 & 6.6 & 11.7 & 12.8 \\
\hline Service & 6.0 & 9.8 & 15.1 & 16.8 \\
\hline Sample size & 60,095 & 58,584 & 59,852 & 56,247 \\
\hline \multicolumn{5}{|c|}{$\begin{array}{l}\text { Sample: people aged 18-64, at work or with a job last week, October Current Population Surveys. Computed } \\
\text { with the supplemental weights, or in } 1997 \text { with the final weights. } \\
\text { a } \text { The classification of educational attainment was revised after the } 1992 \text { CPS. }\end{array}$} \\
\hline
\end{tabular}


TABLE 2 The Spread of Computers Among Older Cohorts:

The percentage and changes in the percentage of workers who use a computer, by cohorts and years

\begin{tabular}{lcccc}
\hline \hline & \multicolumn{4}{c}{ Rates of computer use by cohorts aged ... } \\
& aged 45-49 & aged 50-54 & aged 55-59 & aged 60-64 \\
\hline $\begin{array}{l}\text { Cohorts in 1989 } \\
\text { \% using a computer, 1984 }\end{array}$ & 25.4 & 21.3 & 20.9 & 18.4 \\
$\quad \%$ using a computer, 1989 & 38.6 & 33.8 & 29.7 & 23.3 \\
$\quad$ change, 1984-89 & $13.2^{\text {a }}$ & 12.5 & 8.8 & 4.9 \\
$\begin{array}{l}\text { Cohorts in 1993 } \\
\text { change, 1984-89 }\end{array}$ & 12.9 & 12.6 & 11.8 & 8.9 \\
$\quad$ change, 1989-93 & 11.4 & 8.7 & 7.1 & 4.1 \\
$\begin{array}{l}\text { Cohorts in 1997 } \\
\text { change, 1984-89 }\end{array}$ & 13.9 & 13.3 & 12.2 & 11.0 \\
$\quad \begin{array}{l}\text { change, 1989-93 } \\
\text { change, 1993-97 }\end{array}$ & 8.2 & 11.2 & 8.5 & 6.2 \\
\hline \hline
\end{tabular}

TABLE 3 Rates of Computer Use at Work:

The percentage of workers who use a computer, 1992 HRS (standard errors in parentheses)

\begin{tabular}{llc}
\hline \hline & Age 50-59 & Age 60-62 \\
\hline Among those who work & $48.9(0.7)$ & $41.9(1.6)$ \\
Among users, \% using a computer: & & \\
all of almost all of the time & 40.5 & 40.3 \\
most of the time & 20.1 & 20.1 \\
some of the time & 39.3 & 39.6 \\
\hline \hline Sample: age-eligible workers (born in 1931-1941) in the Health and Retirement Study (N=6,660). \\
Computed with the person level analysis weights.
\end{tabular}




\section{TABLE 4 The Impact of Occupation and Education on Computer Use (OLS regression coefficients, standard errors in parentheses)}

\begin{tabular}{|c|c|c|c|c|}
\hline & \multicolumn{4}{|c|}{ Dependent variable: do you use a computer at work? } \\
\hline & $(1)$ & $(2)$ & $(3)$ & $(4)$ \\
\hline \multicolumn{5}{|c|}{ Age, relative to $60-64$} \\
\hline $18-22$ & $-0.039(0.013)$ & $0.067(0.011)$ & omitted & omitted \\
\hline $23-39$ & $0.165(0.011)$ & $0.153(0.010)$ & $0.107(0.011)$ & $0.128(0.010)$ \\
\hline $40-49$ & $0.185(0.012)$ & $0.141(0.010)$ & $0.144(0.011)$ & $0.118(0.010)$ \\
\hline $50-59$ & $0.112(0.012)$ & $0.083(0.011)$ & $0.085(0.012)$ & $0.076(0.010)$ \\
\hline \multicolumn{5}{|c|}{ Education, relative to $<$ high school $^{\text {a }}$} \\
\hline high school & - & - & $0.254(0.006)$ & $0.109(0.006)$ \\
\hline some college & - & - & $0.454(0.007)$ & $0.202(0.007)$ \\
\hline college + & - & - & $0.602(0.006)$ & $0.278(0.008)$ \\
\hline Occupation dummies & no & yes ${ }^{b}$ & no & yes ${ }^{b}$ \\
\hline Constant & $0.327(0.010)$ & $0.761(0.021)$ & $-0.001(0.011)$ & $0.553(0.024)$ \\
\hline \multicolumn{5}{|c|}{$\begin{array}{l}\text { Sample: workers aged } 18-64 \text { in the October } 1993 \text { CPS. Estimated with supplemental weights and Huber-White } \\
\text { standard errors. All estimates are statistically significant at } 95 \% \text { or higher confidence level. } \\
\text { a Estimates with education dummies omit ages } 18-22 \text {, since people who are not in school at that age are not } \\
\text { representative of the entire sample. } \\
\text { b Occupation dummies for } 45 \text { detailed categories. }\end{array}$} \\
\hline
\end{tabular}

\section{TABLE 5 The Impact of the Spread of Computers on Computer Use (OLS regression coefficients, standard errors in parentheses)}

\begin{tabular}{|c|c|c|c|}
\hline \multirow[b]{2}{*}{$\begin{array}{l}\text { Average computer } \\
\text { use in the same: }\end{array}$} & \multicolumn{3}{|c|}{ Dependent variable: do you use a computer at work? } \\
\hline & (1) age $23-49$ & $\begin{array}{l}\text { Age in } 1993 \\
\text { (2) age } 50-59\end{array}$ & (3) age $60-64$ \\
\hline $\begin{array}{l}\text { Occupation } \\
\text { change, 1989-93 } \\
\text { change, 1984-89 }\end{array}$ & $\begin{array}{rr}0.823^{* *} & (0.022) \\
0.028 & (0.067) \\
-0.012 & (0.050)\end{array}$ & $\begin{array}{cc}0.723^{* *} & (0.054) \\
-0.390^{* *} & (0.145) \\
0.123 & (0.134)\end{array}$ & $\begin{array}{cc}0.528^{* *} & (0.104) \\
-0.897^{* *} & (0.239) \\
-0.020 & (0.250)\end{array}$ \\
\hline $\begin{array}{l}\text { Industry } \\
\text { change, 1989-93 } \\
\text { change, 1984-89 }\end{array}$ & $\begin{array}{c}0.375^{* *}(0.027) \\
-0.120 \\
-0.228^{* *}(0.085) \\
(0.051)\end{array}$ & $\begin{array}{r}0.426^{* *} \\
-1.001^{* *}(0.059) \\
-0.382^{* *}(0.193) \\
(0.128)\end{array}$ & $\begin{array}{cc}0.164 & (0.109) \\
-0.707^{* *} & (0.369) \\
-0.407 & (0.266)\end{array}$ \\
\hline $\begin{array}{l}\text { Occupation } * \\
\text { Industry }\end{array}$ & $0.099^{* *}(0.036)$ & $0.154^{* *}(0.077)$ & $0.556^{* *}(0.135)$ \\
\hline Constant & $-0.085^{* *}(0.007)$ & $(0.016)$ & $0.057^{* *}(0.026)$ \\
\hline
\end{tabular}

Sample: workers in the October 1993 CPS. Estimated with supplemental weights, Huber-White standard errors. Significance at $95 \%\left(^{* *}\right)$ or $90 \%\left(^{*}\right)$ confidence level is noted. The right-hand side variables are levels and changes of average computer use for workers aged 23-49 in 45 occupations and 50 industries. 


\begin{tabular}{|c|c|c|c|c|c|c|c|c|}
\hline \multicolumn{9}{|c|}{$\begin{array}{l}\text { TABLE } 6 \text { Tasks For Which Computers are Used: } \\
\text { The percentage of computer users who use computers for various tasks, } \\
\text { and the average number of tasks per user }\end{array}$} \\
\hline Broad tasks $^{\text {a }}$ & 1989 & 1993 & 1997 & $18-22$ & $23-39$ & $40-49$ & $50-59$ & 60-64 \\
\hline common applications & 60 & 64 & 71 & 54 & 72 & 73 & 73 & 68 \\
\hline accounting tasks & 45 & 45 & 66 & 71 & 68 & 66 & 63 & 61 \\
\hline communication tasks & 31 & 39 & 47 & 31 & 48 & 49 & 49 & 44 \\
\hline analysis & 25 & 26 & 27 & 13 & 28 & 29 & 26 & 21 \\
\hline graphics tasks & 22 & 25 & 26 & 15 & 27 & 27 & 26 & 22 \\
\hline programming & 19 & 13 & 15 & 10 & 16 & 16 & 13 & 11 \\
\hline sales tasks & 16 & 16 & 22 & 23 & 24 & 21 & 20 & 21 \\
\hline instruction & 15 & 16 & - & - & - & - & - & - \\
\hline games & 5 & 6 & - & - & - & - & - & - \\
\hline other & 18 & 19 & 13 & 10 & 12 & 14 & 14 & 14 \\
\hline don't know & 6 & 6 & - & - & - & - & - & - \\
\hline average \# broad tasks & 2.6 & 2.7 & 2.9 & 2.3 & 2.9 & 2.9 & 2.8 & 2.6 \\
\hline average \# specific uses & 3.6 & 4.0 & 4.6 & 3.4 & 4.7 & 4.7 & 4.4 & 4.0 \\
\hline \multicolumn{9}{|c|}{$\begin{array}{l}\text { Sample: see Table } 1 \text { notes. } \\
\text { a The CPS asked about 16- } 22 \text { specific uses, depending on the year, and these have been grouped into broad } \\
\text { tasks; see the appendix for more information. A dash indicates that the task was not asked about that year. }\end{array}$} \\
\hline
\end{tabular}

\begin{tabular}{|c|c|c|c|c|c|c|}
\hline \multicolumn{7}{|c|}{$\begin{array}{l}\text { TABLE } 7 \text { Computer Use and Training at Work: } \\
\text { The percentage of workers who use computers, who feel their computer skills are } \\
\text { adequate, and who have received training }\end{array}$} \\
\hline & All & $18-22$ & $23-39$ & $40-49$ & $50-59$ & $60-64$ \\
\hline$\%$ using a computer & 50.9 & 37.1 & 53.6 & 55.8 & 45.4 & 34.8 \\
\hline$\%$ users using computer less than once/wk & 9.2 & 8.9 & 8.7 & 9.8 & 9.6 & 10.5 \\
\hline once or more/week & 14.1 & 13.8 & 13.9 & 14.2 & 14.6 & 16.9 \\
\hline everyday & 76.8 & 77.3 & 77.5 & 76.0 & 75.8 & 72.7 \\
\hline \multicolumn{7}{|c|}{$\%$ who feel their computer skills are good enough for the current job: } \\
\hline computer users & 88.4 & 93.6 & 89.1 & 86.8 & 86.6 & 85.8 \\
\hline non-computer users & 59.2 & 71.4 & 59.6 & 57.3 & 54.4 & 51.9 \\
\hline$\%$ who got any training in the current job & 42.6 & 25.1 & 43.1 & 48.8 & 42.8 & 34.7 \\
\hline of those, $\%$ trained in computer skills & 32.7 & 21.9 & 32.1 & 35.4 & 34.3 & 29.4 \\
\hline
\end{tabular}




\begin{tabular}{|c|c|c|c|}
\hline \multicolumn{4}{|c|}{$\begin{array}{l}\text { TABLE } 8 \text { Computer Use and Retirement: } \\
\text { Among people working initially, the percentage still working years later } \\
\text { (standard errors in parentheses) }\end{array}$} \\
\hline if working in ..., \% still working later in ...: & $1992 \rightarrow 96$ & $1992 \rightarrow 94$ & $1994 \rightarrow 96$ \\
\hline All workers aged 50-62 in 1992 & $75.6(0.6)$ & $85.1(0.5)$ & $83.8(0.5)$ \\
\hline computer users & $78.4(0.8)$ & $87.0(0.6)$ & $85.9(0.7)$ \\
\hline non-computer users & $73.0(0.8)$ & $83.3(0.6)$ & $81.7(0.8)$ \\
\hline
\end{tabular}

\begin{tabular}{|c|c|c|c|}
\hline \multicolumn{4}{|c|}{$\begin{array}{l}\text { TABLE } 9 \text { Explaining Computer Use: } \\
\text { (OLS regression coefficients, first-stage estimates, standard errors in parentheses) }\end{array}$} \\
\hline & \multicolumn{3}{|c|}{$\begin{array}{l}\text { Dependent variable: the person uses a computer } \\
\begin{array}{lll}(1) & (2) & (3)\end{array}\end{array}$} \\
\hline $\begin{array}{l}\text { Average occupational computer use } \\
\text { change, 1993-97 }\end{array}$ & $0.580^{* *}(0.064)$ & $0.412^{* *}(0.064)$ & $\begin{array}{r}0.326^{* *}(0.078) \\
-0.476^{* *}(0.185)\end{array}$ \\
\hline $\begin{array}{l}\text { Average industry computer use } \\
\text { change, } 1993-97\end{array}$ & $0.109^{*}(0.061)$ & $\begin{array}{cl}-0.028 & (0.065) \\
-\end{array}$ & $\begin{array}{l}-0.284^{* *}(0.100) \\
-1.053^{* *}(0.326)\end{array}$ \\
\hline Occupation*industry average & $0.569^{* *}(0.120)$ & $0.548^{* *}(0.118)$ & $0.466^{* *}(0.120)$ \\
\hline $\mathrm{R}^{2}$ & 0.288 & 0.355 & 0.358 \\
\hline Includes other covariates? & no & yes & yes \\
\hline
\end{tabular}

Sample: HRS, see Table 10 notes. Estimated with the person-level analysis weights and Huber-White standard errors. Significance at $95 \%\left(^{* *}\right)$ or $90 \%\left(^{*}\right)$ confidence level is noted. Independent variables: average computer use of workers aged 23-49 in the same occupation and industry, 1993 CPS. 
TABLE 10 Explaining Retirement:

(OLS regression coefficients, standard errors in parentheses)

\begin{tabular}{|c|c|c|c|c|}
\hline & \multicolumn{4}{|c|}{ Dependent variable: the person is still working, $1992 \rightarrow 96$} \\
\hline & OLS-1 & OLS-2 & OLS-3 & OLS-4 \\
\hline Uses a computer & $\begin{array}{l}0.033^{* *} \\
(0.012)\end{array}$ & - & $\begin{array}{c}0.010 \\
(0.013)\end{array}$ & $\begin{array}{l}0.022^{*} \\
(0.014)\end{array}$ \\
\hline $\begin{array}{l}\text { Education: } \\
\text { high school } \\
\text { some college } \\
\text { college }+\end{array}$ & - & $\begin{array}{c}0.074^{* *} \\
(0.019) \\
0.095^{* *} \\
(0.021) \\
0.127^{* *} \\
(0.021)\end{array}$ & $\begin{array}{c}0.071^{* *} \\
(0.019) \\
0.091^{* *} \\
(0.021)^{*} \\
0.122^{* *} \\
(0.022)\end{array}$ & $\begin{array}{c}0.070^{* *} \\
(0.019) \\
0.087^{* *} \\
(0.022) \\
0.126^{* *} \\
(0.023)\end{array}$ \\
\hline Also includes & age & \multicolumn{2}{|c|}{$\begin{array}{l}\text { age, demographic } \\
\text { characteristics }\end{array}$} & $\begin{array}{l}\text { age, demographic and } \\
\text { job characteristics }\end{array}$ \\
\hline Uses a computer & $\begin{array}{l}0.028^{* *} \\
(0.010)\end{array}$ & pendent $\mathrm{v}$ & $\begin{array}{l}\text { same, } 195 \\
0.016 \\
(0.011) \\
\end{array}$ & $\begin{array}{c}0.012 \\
(0.011) \\
\end{array}$ \\
\hline Uses a computer & $\begin{array}{l}0.027^{* *} \\
(0.012) \\
\end{array}$ & $\begin{array}{c}\text { pendent } \mathrm{v} \\
-\end{array}$ & $\begin{array}{l}\text { same, } 195 \\
0.010 \\
(0.012) \\
\end{array}$ & $4 \rightarrow 96$ \\
\hline $\begin{array}{l}\text { Sample: HRS, worke } \\
\text { values for demograph } \\
\text { Huber-White standar } \\
\text { variables are race, sex }\end{array}$ & $\begin{array}{l}50-62 \text { in } \\
\text { job chara } \\
\text { rs. Signific } \\
\text { ital status. }\end{array}$ & $\begin{array}{l}\text { th hourly ea } \\
(\mathrm{N}=5152) \text {. } \\
5 \%\left(^{* *}\right) \text { or } 9 \\
\text { phic }+ \text { vari }\end{array}$ & $\begin{array}{l}\text { ween } \$ 1 \text { anc } \\
\text { with the pe } \\
\text { fidence lev } \\
\text { sted in the a }\end{array}$ & $\begin{array}{l}\$ 100 \text { and non-missing } \\
\text { on-level analysis weights, } \\
\text { s is noted. Demographic } \\
\text { pendix. }\end{array}$ \\
\hline
\end{tabular}




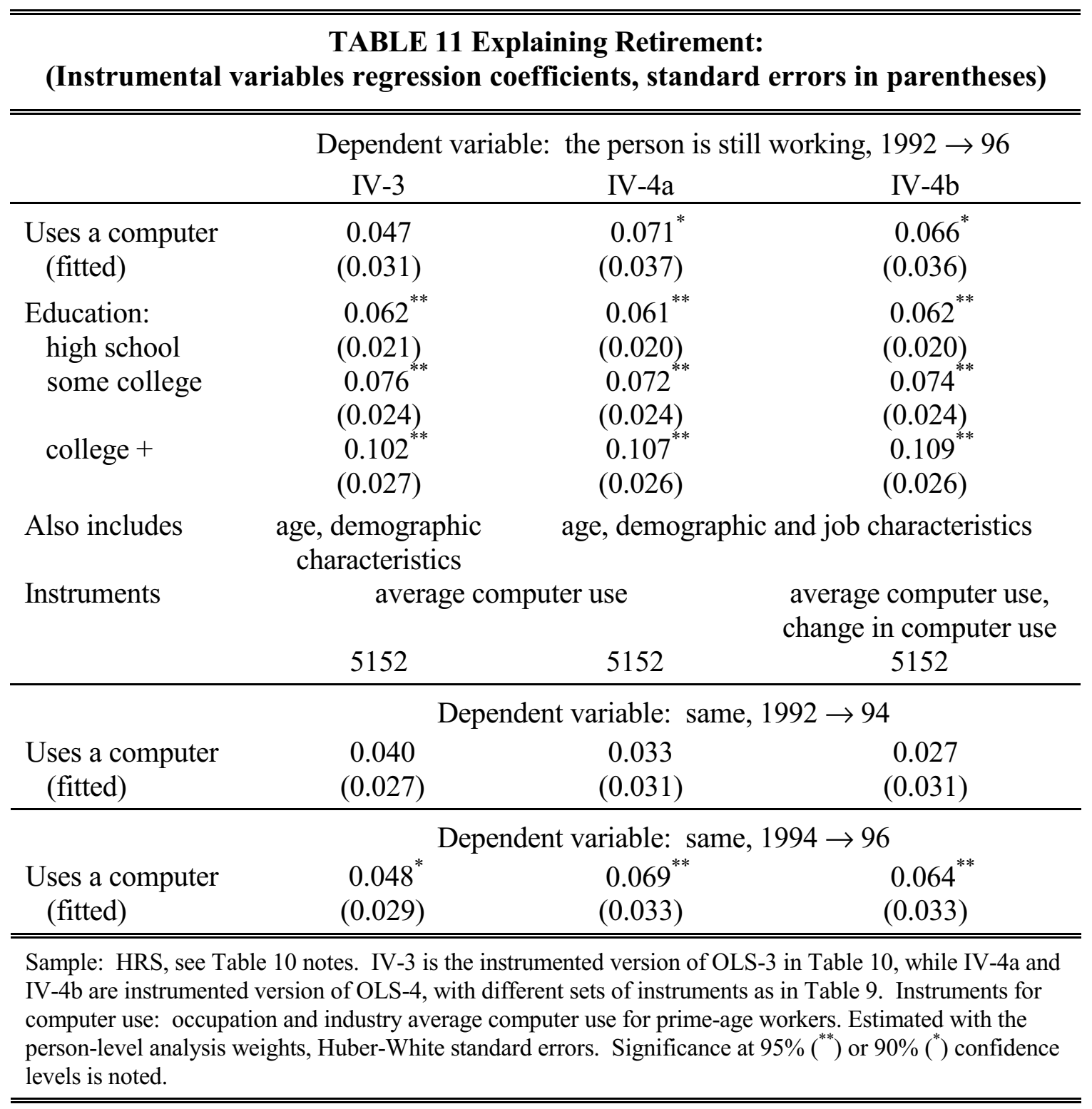




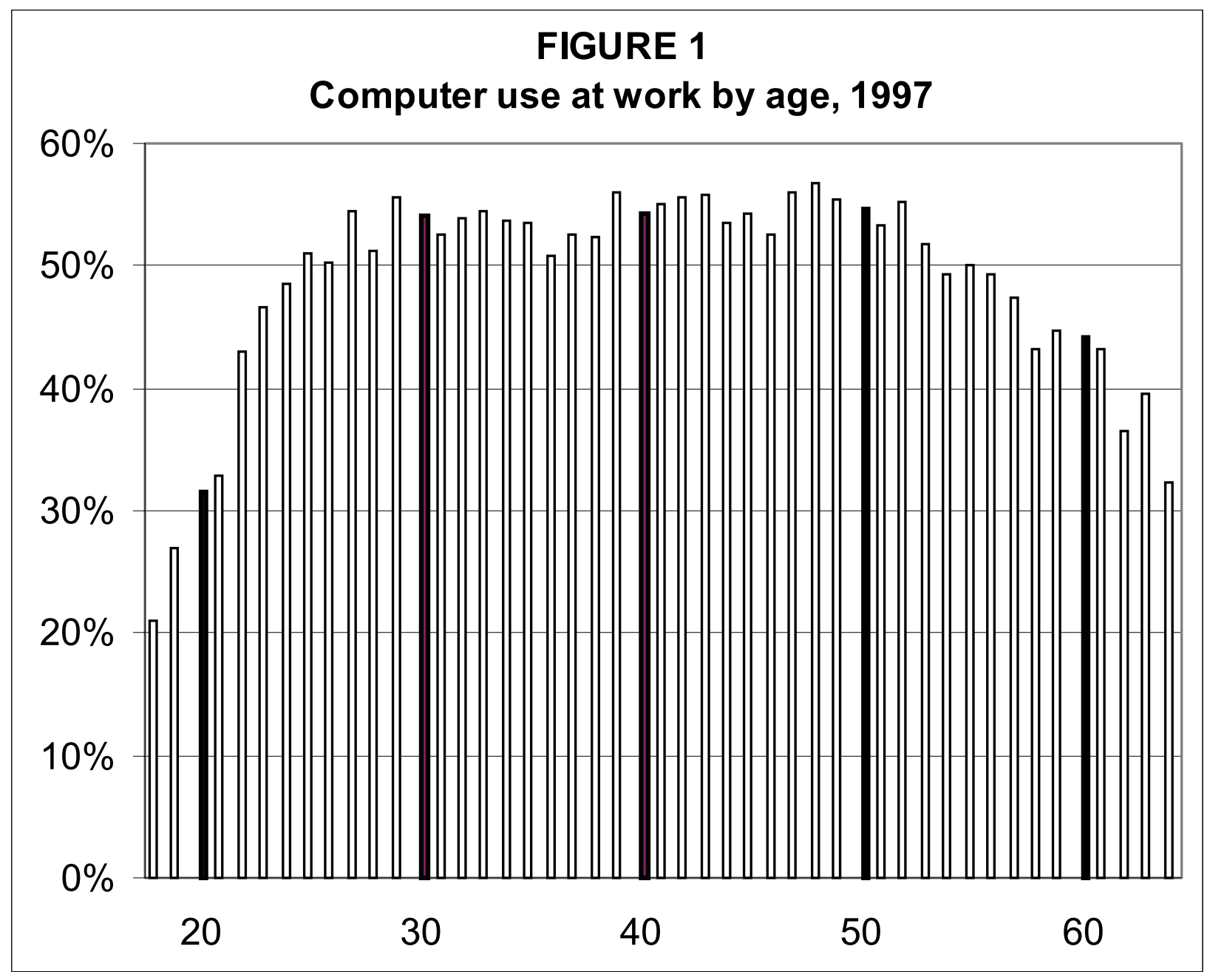




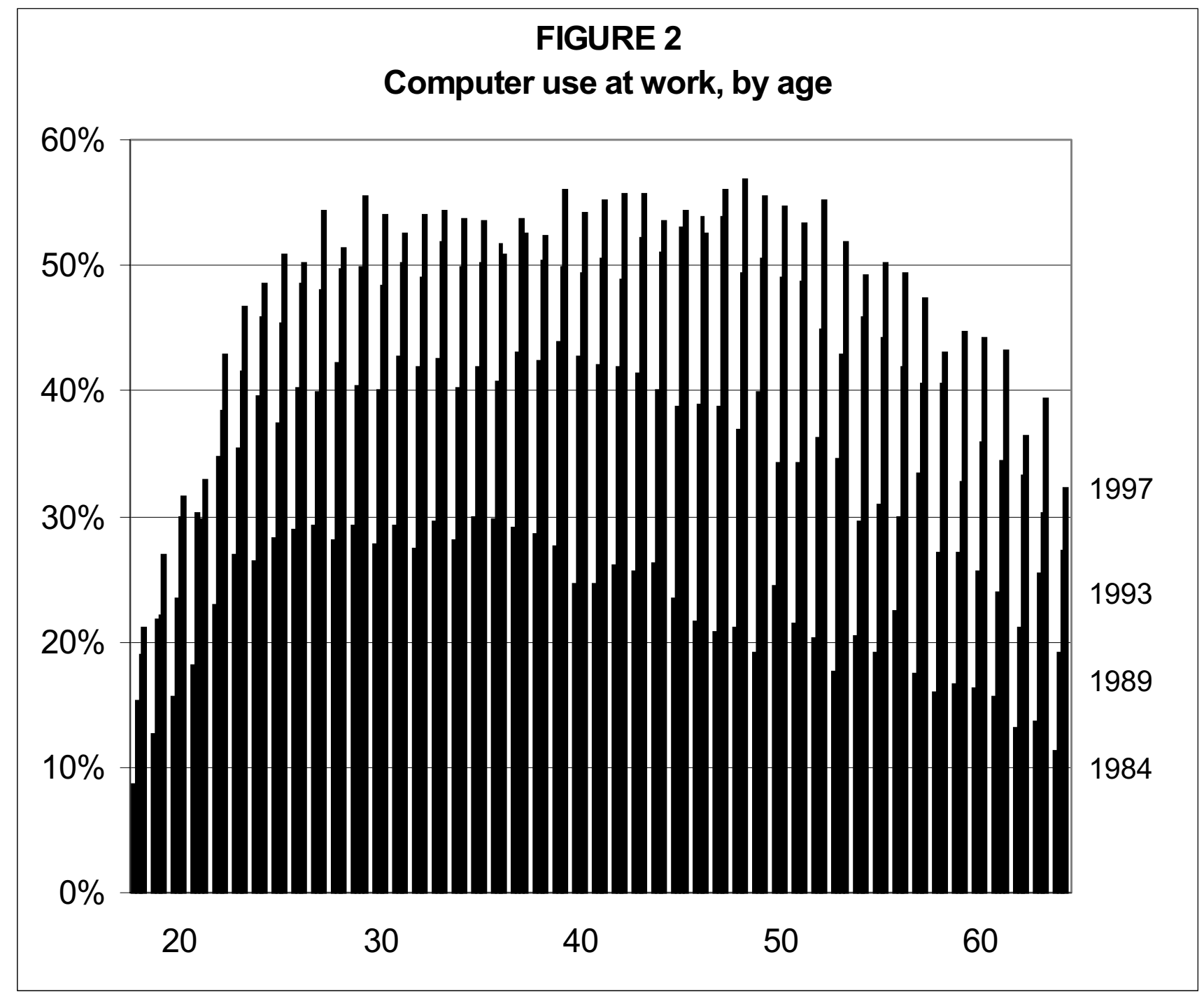




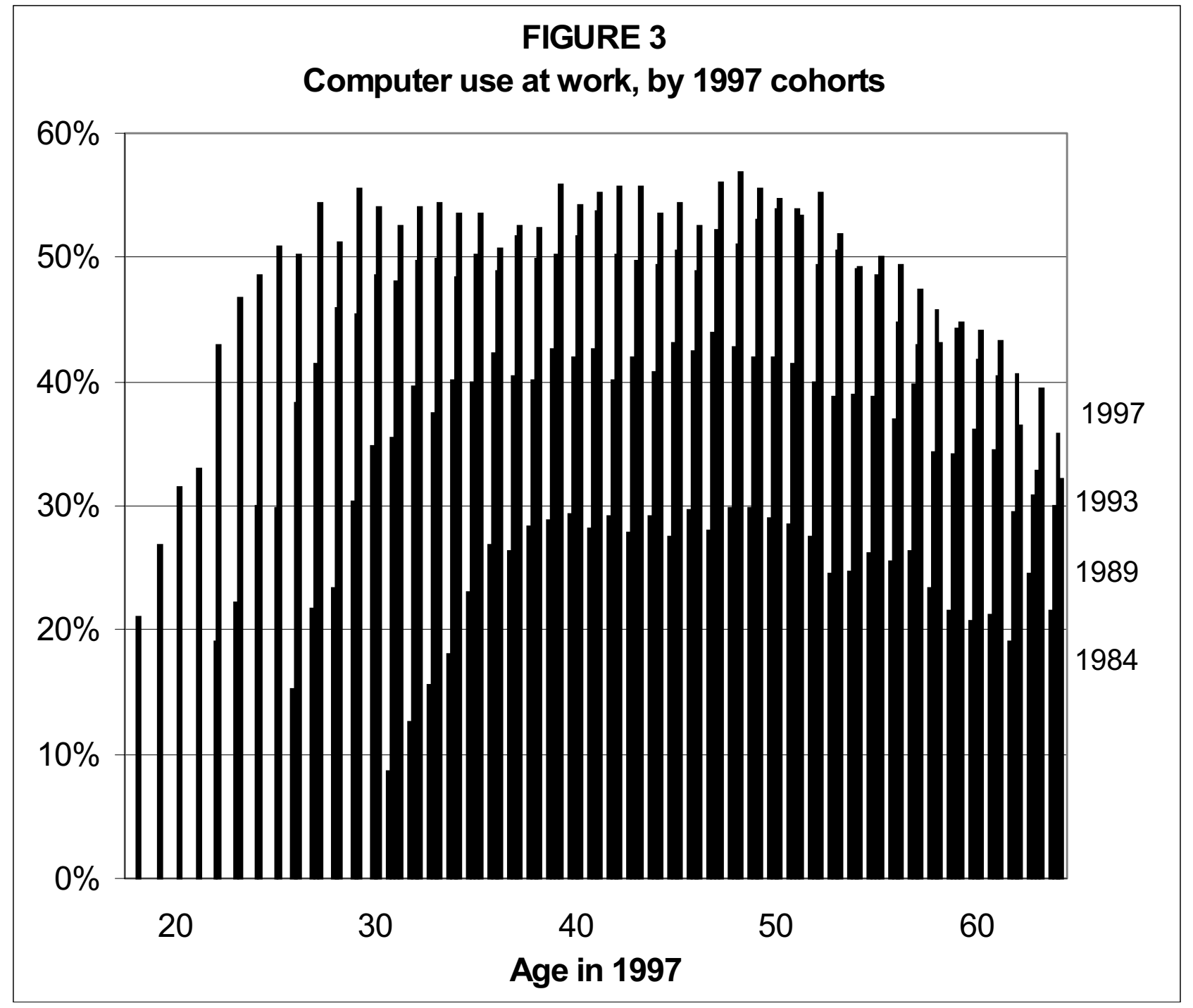




\section{DATA APPENDIX}

\section{What did people use computers for?}

The CPS computer use supplements since 1989 have asked workers what they used computers for. Respondents were allowed to choose any number of about two dozen possible tasks. I grouped the specific uses into a variety of broad tasks that appear in Table 6. Common applications are word processing, databases, spreadsheets, and calendar/scheduling; communication tasks are communication, electronic mail, and bulletin boards (1993 only); accounting tasks are bookkeeping, inventory control, invoicing, and customer records and accounts (1997); sales tasks are sales, marketing, and telemarketing (1993); graphics tasks are graphics, design, desktop publishing, newsletters, and computer assisted design; programming; analysis; learning tasks are learning to use the computer (1993), educational programs (1993), and instruction (1989); games; other; and don't know (1989 and 1993 only).

\section{Retirement patterns by occupation and industry in the 1970s}

In the last section of the paper I include controls for retirement patterns by occupation and industry from a time period before computers were important. Since there is no longitudinal retirement data from the late 1970s, I calculated a measure of retirement patterns using data from the outgoing rotation groups of the March CPS of 1977-80, and for comparison, 1983-84 and 1992-93. Until 1993, people were asked about their last occupation and industry if they were not working but had worked in the last 5 years.

I used this data to construct a summary statistic for retirement by occupation and industry at ages 60-62. I chose these ages because about half of workers retire by age 62, while at older ages many people will have retired more than 5 years earlier; this missing data could cause selection bias if people in some jobs retire earlier on average.

The statistic I computed is the "work rate" for each occupation and industry: the proportion who are currently working, relative to the total number who work or used to work in that occupation and industry in the last 5 years. The resulting work rates range from 0.802 for managerial specialties to 0.606 for transport operators. Occupation codes changed substantially after 1982, so I also computed work rates for 1983-84, using consistent with today's codes; the estimation results were unchanged. Consistent occupation and industry codes for 1970, 1980, and 1990 were helpfully provided by David Autor.

\section{Additional variables from the HRS}

Below are descriptions and coefficient estimates for additional variables included in regressions OLS-4 and IV-4a. More details are available in Friedberg (1999).

(1) Usual retirement age in your job, relative to your age. From question F90, "What is the usual retirement age for people who work with you or have the same kind of job in your job." Omitted category: 3 or more years younger than usual retirement age.

(2) Average of the usual retirement age in your occupation and industry, relative to your age. Variable in (1), averaged over the sample using the person-level analysis weights.

(3) Pension plan in your job, and your age relative to age when benefits are first available. From questions F39, F45, F48. Omitted category: no pension plan. 
(4) Health insurance coverage. From questions R2-R15a. No health insurance is defined as none from the government, a current or former employer, or purchased directly from an insurer. Retiree health insurance is coded from R8, asking whether the employer has "any health insurance plan available to retirees."

(5) Log hourly earnings. Hourly pay on the main job (F16d), if the person is paid by the hour. Otherwise, earnings on the main job divided by the product of usual hours per week and weeks worked last year, based on questions F16a, F30a, F8, F10.

(6) Log liquid wealth. The natural log of variable 5354, "Net Worth: Liquid assets".

(7) Expects to receive or receives Social Security. From questions N46 and N41.

(8) Hospitalization. From questions B45 and B45a in wave 1, B29 and B29a in wave 2, E1 and E2 in the 1998 release of wave 3. Omitted category: not hospitalized.

(9) Education. Less than high school: no diploma or equivalency test $(\mathrm{A} 3 \mathrm{a}=5)$ or if A3a not answered then high grade completed (A3) is less than 12. High school: diploma or equivalency test, or if A3a not answered then high grade completed is 12. Some college: highest degree earned is Associates $(\mathrm{A} 3 \mathrm{~d}=1)$ or if no degree reported then high grade completed is greater than 12. 4-year college degree or more: answers 2-7 reported for highest degree in A3d. Omitted category: less than high school.

(10) Demographics. Married: question A10. Female: question 47. Race: question 48. Omitted categories: not married, male, race is white.

(11) Was married in wave 1, not in later waves. From question A10 in wave 1, A1 in wave 2, E256A in the 4/99 release of wave 3.

(12) Age. From question 46.

Work: Working for pay, in questions F2 in wave 1, FA2 in wave 2, G3 in wave 3. Industry: Question F4. Occupation: Questions F5, F6. 


\begin{tabular}{|c|c|c|c|}
\hline \multicolumn{4}{|c|}{ Additional Regression Coefficients } \\
\hline $1992 \rightarrow 96$ & Mean (s.d.) & OLS-4 (s.e.) & IV-4a (s.e.) \\
\hline $\begin{array}{l}\text { (1) } 1-2 \text { years younger than usual retirement age } \\
\text { in your job (dummy) }\end{array}$ & $0.051(0.220)$ & $-0.117^{* *}(0.036)$ & $-0.116^{* *}(0.036)$ \\
\hline Age $=$ usual retirement age $(\mathrm{d})$ & $0.008(0.089)$ & $-0.354^{* *}(0.080)$ & $-0.356^{* *}(0.080)$ \\
\hline Age $>$ usual retirement age $(\mathrm{d})$ & $0.020(0.140)$ & $-0.051(0.053)$ & $-0.046(0.054)$ \\
\hline Usual age not reported $(\mathrm{d})$ & $0.302(0.459)$ & $-0.013(0.014)$ & $-0.011(0.014)$ \\
\hline (2) Age-average age of usual retirement, occup & $7.500(3.177)$ & $0.005(0.013)$ & $0.001(0.013)$ \\
\hline Age-average age of usual retirement, industry & $7.521(3.207)$ & $-0.001(0.009)$ & $-0.000(0.009)$ \\
\hline (3) DB pension, your age $>$ pension ret age (d) & $0.091(0.287)$ & $-0.121^{* *}(0.028)$ & $-0.134^{* *}(0.029)$ \\
\hline $\mathrm{DB}$, your age $=$ pension retirement age $(\mathrm{d})$ & $0.039(0.194)$ & $-0.083^{* *}(0.037)$ & $-0.094^{* *}(0.038)$ \\
\hline $\mathrm{DB}$, your age < pension retirement age $(\mathrm{d})$ & $0.251(0.434)$ & $-0.017(0.017)$ & $-0.026(0.018)$ \\
\hline $\mathrm{DB}$, no pension retirement age reported (d) & $0.018(0.134)$ & $-0.014(0.042)$ & $-0.024(0.043)$ \\
\hline Has DC pension only (d) & $0.183(0.386)$ & $0.006(0.018)$ & $-0.004(0.019)$ \\
\hline (4) Has health insurance from an employer (d) & $0.826(0.380)$ & $0.060^{* *}(0.028)$ & $0.057^{* *}(0.029)$ \\
\hline Has retiree hlth insurance frm an employer (d) & $0.578(0.494)$ & $-0.076^{* *}(0.014)$ & $-0.074^{* *}(0.014)$ \\
\hline Has health insurance from the government (d) & $0.075(0.264)$ & $-0.035(0.025)$ & $-0.036(0.025)$ \\
\hline Has health insurance purchased privately (d) & $0.168(0.374)$ & $0.016(0.020)$ & $0.017(0.020)$ \\
\hline Has no health insurance (d) & $0.084(0.278)$ & $-0.025(0.035)$ & $-0.025(0.035)$ \\
\hline (5) Log hourly earnings & $2.440(0.663)$ & $-0.009(0.011)$ & $-0.014(0.012)$ \\
\hline (6) Log liquid wealth (if wealth $>0$ ) & $7.898(3.136)$ & $-0.002(0.004)$ & $-0.003(0.004)$ \\
\hline Liquid wealth $=0(\mathrm{~d})$ & $0.101(0.301)$ & $-0.077^{* *}(0.038)$ & $-0.078^{* *}(0.038)$ \\
\hline (7) Expects to receive Social Security (d) & $0.939(0.239)$ & $-0.007(0.025)$ & $-0.009(0.025)$ \\
\hline (8) Hospitalized once, year before wave 1 (d) & $0.055(0.229)$ & $-0.058^{* *}(0.029)$ & $-0.057^{*}(0.029)$ \\
\hline Hospitalized $2+$ times in 1991 & $0.013(0.114)$ & $-0.117^{*}(0.060)$ & $-0.114^{*}(0.060)$ \\
\hline Hospitalized once between 1992-94 (d) & $0.101(0.301)$ & $-0.037^{*}(0.022)$ & $-0.038^{*}(0.022)$ \\
\hline Hospitalized $2+$ times between 1992-94 (d) & $0.032(0.177)$ & $-0.140^{* *}(0.039)$ & $-0.139^{* *}(0.039)$ \\
\hline Hospitalized once between 1994-96 (d) & $0.116(0.320)$ & $-0.051^{* *}(0.020)$ & $-0.051^{* *}(0.020)$ \\
\hline Hospitalized 2+ times between 1994-96 (d) & $0.044(0.205)$ & $-0.142^{* *}(0.037)$ & $-0.142^{* *}(0.037)$ \\
\hline (9) High school diploma (d) & $0.381(0.486)$ & $0.070^{* *}(0.019)$ & $0.061^{* *}(0.020)$ \\
\hline Some college $(\mathrm{d})$ & $0.223(0.416)$ & $0.087^{* *}(0.022)$ & $0.072^{* *}(0.024)$ \\
\hline Four-year college degree or more (d) & $0.228(0.419)$ & $0.126^{* *}(0.023)$ & $0.107^{* *}(0.026)$ \\
\hline (10) Married in 1992, spouse younger (d) & $0.464(0.499)$ & $0.075^{* *}(0.025)$ & $0.075^{* *}(0.025)$ \\
\hline Married in 1992, spouse is older (d) & $0.269(0.443)$ & $0.066^{* *}(0.030)$ & $0.064^{* *}(0.030)$ \\
\hline Married in 1992, don't know spouse age (d) & $0.013(0.112)$ & $0.148^{* *}(0.046)$ & $0.149^{* *}(0.045)$ \\
\hline Female $(\mathrm{d})$ & $0.463(0.499)$ & $0.024(0.029)$ & $0.015(0.030)$ \\
\hline Female, married in 1992 (d) & $0.293(0.455)$ & $-0.144^{* *}(0.034)$ & $-0.143^{* *}(0.034)$ \\
\hline Race $=$ black $(d)$ & $0.085(0.279)$ & $0.046^{*}(0.024)$ & $0.048^{*}(0.024)$ \\
\hline Race $=$ other nonwhite $(d)$ & $0.066(0.249)$ & $-0.005(0.029)$ & $-0.004(0.029)$ \\
\hline Female, race $=$ black $(\mathrm{d})$ & $0.048(0.214)$ & $-0.031(0.034)$ & $-0.025(0.034)$ \\
\hline Female, race $=$ other nonwhite $(\mathrm{d})$ & $0.029(0.168)$ & $0.045(0.043)$ & $0.045(0.043)$ \\
\hline (11) Was married in 1992, not 1994 (d) & $0.019(0.135)$ & $-0.015(0.049)$ & $-0.019(0.049)$ \\
\hline Female, was married in 1992, not 1994 (d) & $0.010(0.102)$ & $0.153^{* *}(0.067)$ & $0.156^{* *}(0.068)$ \\
\hline Was married in 1994, not 1996 (d) & $0.020(0.140)$ & $-0.049(0.055)$ & $-0.051(0.056)$ \\
\hline Female, was married in 1994, not 1996 (d) & $0.001(0.099)$ & $0.086(0.080)$ & $0.093(0.080)$ \\
\hline
\end{tabular}

